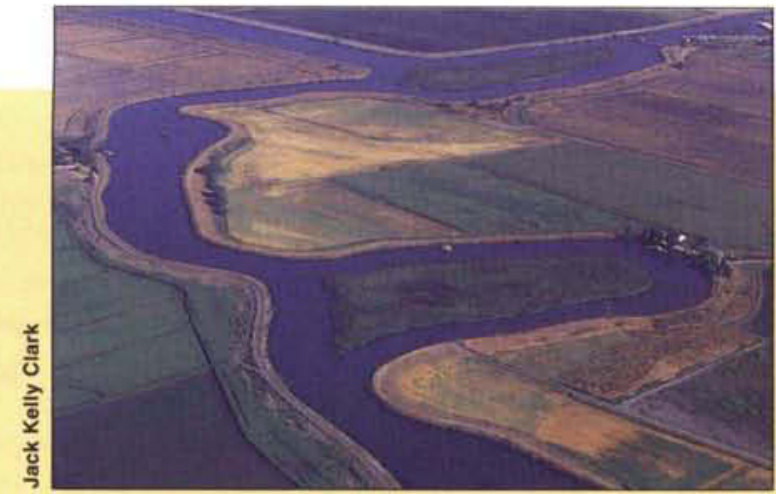

\section{A truce in the water wars}

\author{
Michael P. Marchetti $\square \quad$ Peter B. Moyle
}

The conflict over water diversions from the Sacramento-San Joaquin Delta has been one of the longest and most severe of California's water wars. This conflict developed in 1951 when the massive pumps of the federal Central Valley Project began pumping water from the south Delta to supply water to San Joaquin Valley farms. In 1962 , the equally massive pumps of the State Water Project also began pumping water from the south Delta to both farms and urban areas in the southern half of the state. The pumping contributed to drastic changes in the Delta ecosystem. These changes caused practically every aquatic organism to decline in abundance. This decline was most noticeable in the catches of anglers fishing for the Delta's top predator, the striped bass. In 1989 the winter run chinook salmon was listed as a threatened species by the U.S. Fish and Wildlife Service. It is now listed as endangered by both state and federal governments. By 1992 the damage to the Delta was so great that the delta smelt, a species found nowhere else, was put on the federal list of threatened species. A number of other fish species such as longfin smelt, splittail and spring run chinook salmon are likely to be listed if their populations continue to decrease.

Recent disputes over diversions from the Delta led to an unprecedented agreement among state and federal agencies, water users, and environmental groups. Announced on
December 15, 1994, it signalled a 3-year truce in the water wars. The provisions of the agreement reflect the aims of the federal Endangered Species Act, and Clean Water Act, as well as the desire of water interests to have a predictable water supply. During the 3-year "truce," efforts will be made by all signatories, according to the agreement, to "provide ecosystem protection to the BayDelta estuary" and to "provide habitat protection sufficient for currently listed threatened and endangered species and to create conditions in the Bay-Delta Estuary that avoid the need for any additional listings in the next three years." In the interim, the agreement provides additional water for the estuary, especially during the critical periods (e.g., spring migration times of juvenile salmon) when young fish need to pass through the estuary to reach rearing areas in the middle estuary (Suisun Bay). Besides providing more water to the Delta, the agreement stipulates that the water users will give $\$ 10$ million per year for projects involving other ways of improving Delta habitats such as increasing the amount of shallow-water habitat for juvenile fishes. The total cost of these projects is estimated to be about
Upper left, the Sacramento-San Joaquin Delta has been the subject of long-running water wars. In 1962, massive pumps, above, began pumping water from the south Delta to farms and urban areas in the southern half of the state. (Photo by Jack Kelly Clark)

$\$ 60$ million per year. In exchange, the agreement gives the water users a guaranteed water supply. Thus, even if more Delta fish species are listed as endangered during the next three years, no additional water will be allocated to the Delta. Equally important to the water users, all of the federal water used for environmental protection will be credited against the 800,000 acre feet of water that the Central Valley Project Improvement Act allocates to fish and wildlife in the Central Valley.

If all goes as planned, the downward trend in Delta fish populations will be reversed and water users will be able to plan better for water use, even if they have less water to work with than they had in the past. 